\title{
The backlash against biofuels
}

\author{
KURT KLEINER
}

\section{While the US and EU plan major investments in bioethanol and biodiesel, critics argue that biofuels carry too high a cost. Kurt Kleiner reports.}

$$
\text { L }
$$

ast month Jean Ziegler, the UN special rapporteur on the right to food, called biofuels a "crime against humanity" and asked for a five-year moratorium on the practice of using food crops for fuel ${ }^{1}$.

It was only the latest voice in what seems to be turning into a backlash against biofuels. In September, the Organisation for Economic Co-operation and Development issued a sceptical assessment of biofuels, warning that they could cause more problems than they solve ${ }^{2}$.

Even the celebrated primatologist Jane Goodall got involved in September, warning that the demand for more biofuels is causing rainforests to be cut down to grow more sugar cane and oil palms.

For decades, biofuels seemed to promise a clean, sustainable, environmentally friendly way to produce fuel, one that would promote energy independence and at the same time reduce greenhouse gas emissions. But even as governments and corporations are finally throwing their weight behind biofuel production, a small but vocal chorus of critics claims that biofuels are at best a waste of effort and at worst outright damaging. Some critics even question whether biofuels will lower greenhouse gas emissions or actually increase them.

"People are getting smarter. People are beginning to see that the damage ensuing from producing agrofuels by far outweighs any possible benefits," says Tad W. Patzek, a professor of geoengineering at the University of California, Berkeley, and a prominent biofuels sceptic.

Criticism of biofuels comes from several directions. Some critics argue that biofuels will demand more energy than they produce. Others think that biofuels will use up resources that would otherwise go to feeding people. Still others worry about the environmental damage that will be caused by farming of more land - damage that they say could result in higher greenhouse gas emissions. It is even cast as an issue of human rights, as critics worry that more indigenous people will be forced from their land to make way for biofuel plantations.

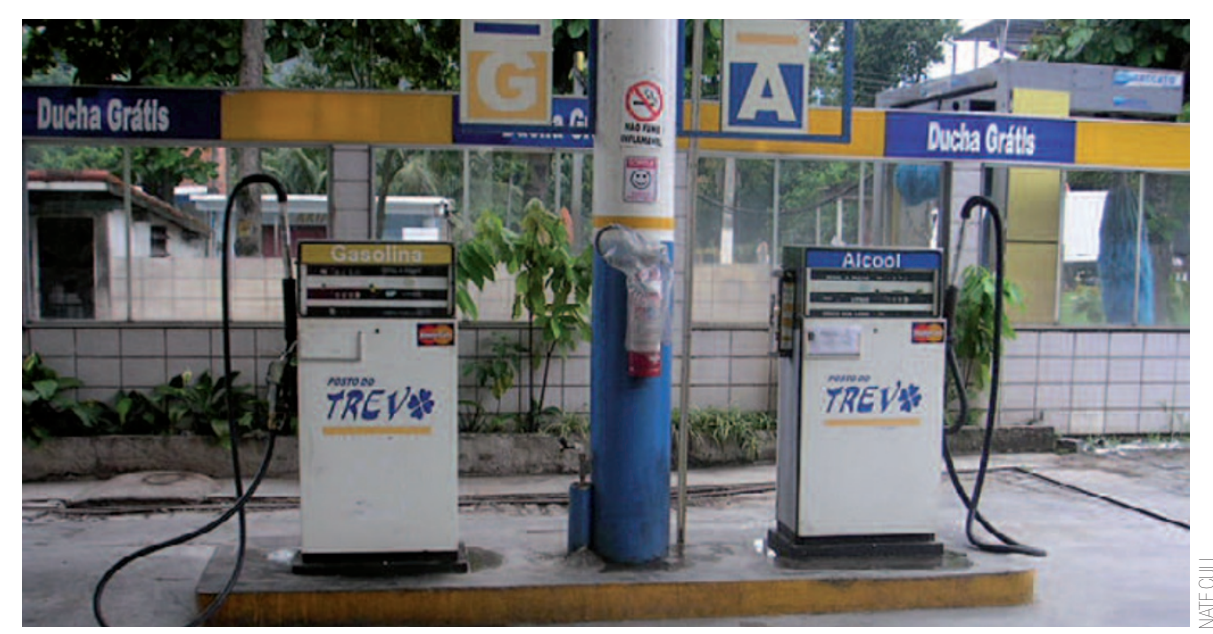

Gasoline on the left, bioethanol on the right at a filling station in Brazil.

"I think a lot of environmentalists got caught with their pants down. They were thinking of biofuels in a local, non-industrial way. When agroindusty and oil companies got ahold of it, they turned it into something that is by no means sustainable," says Eric Holt-Gimenez, executive director of the FoodFirst Institute for Food and Development Policy in Oakland, California.

\section{People are getting smarter. People are beginning to see that the damage ensuing from producing agrofuels by far outweighs any possible benefits.}

Tad W. Patzek

Although ethanol was used as a transport fuel early in the twentieth century, it was the oil shocks of the 1970s that prompted the US government and others to encourage homegrown bioethanol industries through tax breaks, regulation and research grants. But for much of that time the use of biofuels has struggled against a relatively low petroleum price that has made it hard for them to be cost-competitive.

Now, with oil prices in the US approaching triple digits, worries about potentially dwindling oil supplies and the threat of climate change have combined to give biofuels a boost that supporters think will make them a practical fuel source.

Global ethanol production was 13.4 billion gallons in 2006, according to the Renewable Fuels Association ${ }^{3}$. The US led production at 4.8 billion gallons, mostly produced from corn, and Brazil was close behind, producing 4.5 billion gallons, mostly from sugar cane. Production increased 20 percent between 2004 and 2006.

New efforts by the US and the EU promise to increase that production further. The US government has announced a goal of doubling ethanol production again by 2012 , and the EU has announced a goal of making ten percent of transport fuelled from biofuel by the 2020 .

Although technically a biofuel is any fuel that can be derived from biomass, including firewood, the term is usually applied to liquid fuels that can be used for transportation. By that definition, the two most plentiful biofuels produced today are bioethanol and biodiesel. 
Bioethanol is made by first fermenting a starchy or sugary feedstock such as corn or sugar cane, then distilling the alcohol in a process not unlike making whiskey or rum. Biodiesel, in contrast, is produced from vegetable oils such as palm or soy oil through a transesterification process that makes the oil suitable for burning in diesel engines.

\section{NET ENERGY}

The first question regarding biofuels is whether they can provide enough energy to be worth the effort. Fossil fuels come out of the ground in a form that is relatively energy-dense - their pre-processing has been accomplished by geological forces over millions of years. Corn and sugar cane, on the other hand, are much less energy-efficient. It takes about 2.7 kilograms of corn, or 12 kilograms of sugar cane, to produce a litre of ethanol.

Of course, the energy in biofuels comes free from the sun. But to harvest, transport and process the feedstock requires tractors, trucks and production facilities, all of which need energy for their building and operation. The crops also require nitrogen fertilizer, which is derived from natural gas. Critics say that all the effort isn't worth it, at least in terms of net energy.

Patzek and his colleague David Pimentel, a professor of insect ecology and agricultural sciences at Cornell University, have done a number of analyses on the energy requirements of various biofuels. In a 2005 paper, they attempted to quantify all of the energy inputs required to produce and process a feedstock into ethanol ${ }^{4}$.

When using corn as a feedstock, they concluded, it took 6,597 kilocalories of energy to produce the ethanol, whereas the ethanol would yield only 5,130 kilocalories. In other words, biofuels actually use more energy than they provide. Patzek and Pimentel also calculated that the cost of a litre of ethanol is US\$1.24, compared with 33 cents for a litre of gasoline. Their analyses of ethanol from other feedstocks, and of biodiesel, were equally discouraging.

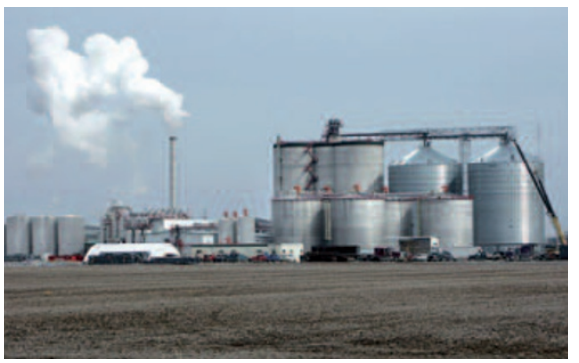

A typical ethanol plant in West Burlington, lowa. Researchers disagree on whether burning bioethanol generates more energy than is used to produce the fuel.

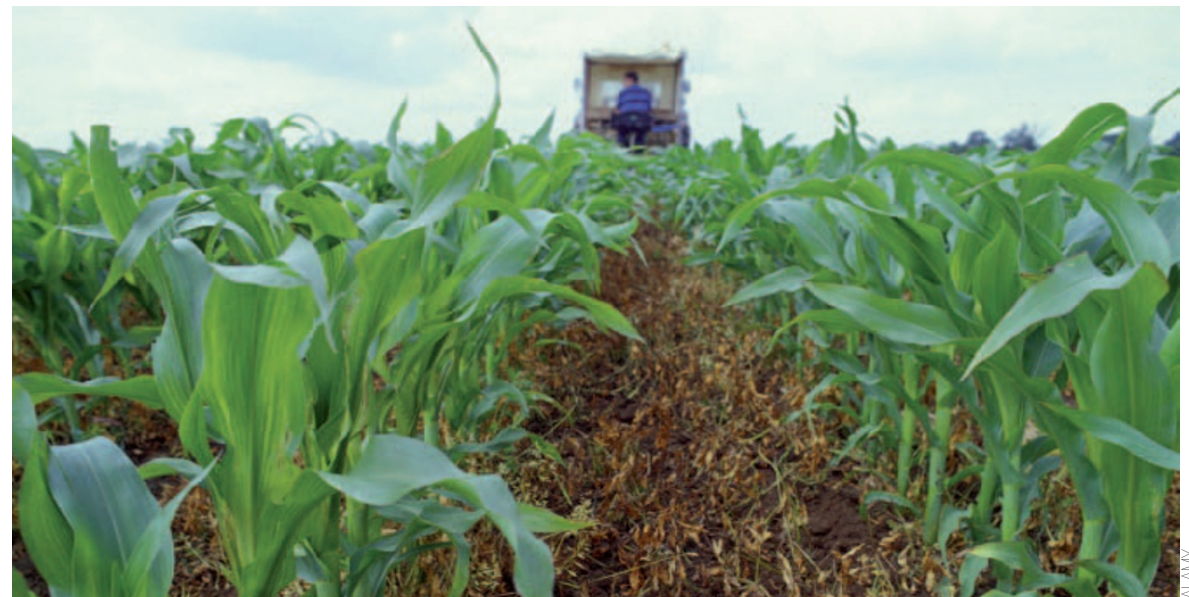

Turning food crops such as corn into fuel is a "crime against humanity", says the UN rapporteur on the right to food.

But many other researchers have found net energy gains from biofuels. In a paper presented to the International Symposium on Alcohol Fuels in September 2005, Michael Wang, a fuel systems analyst at Argonne National Laboratory at the University of Chicago, concluded that it takes only 0.74 British thermal units (Btu) of fossil energy to produce one million Btu of ethanol from corn ${ }^{5}$.

Other researchers have come up with similar numbers. In a paper published in Science in 2006, Alexander E. Farrell, an energy policy analyst at the University of California, Berkeley, and colleagues looked at six studies and concluded that ethanol does have a net energy benefit ${ }^{6}$.

But Bruce Dale, a chemical engineer at Michigan State University, argues that a net energy analysis is largely irrelevant because it ignores the fact that we value different energy carriers in different ways. For instance, it takes three megajoules of energy from coal to create one megajoule of energy from electricity. But electricity is useful to us in a way that heat from coal is not, so we're willing to pay the price. In the same way, we're willing to pay a price for liquid fuel that we can put in our tanks, Dale says.

Because we're trying to use biofuels to replace liquid fuel for transporation, he says, one of the most important metrics is not the total energy used to create the ethanol, but the amount of petroleum it displaces. He calculates that each megajoule of energy from bioethanol displaces 22 megajoules of energy from petroleum.

\section{EXTRA EMISSIONS}

Replacing petroleum with biofuels should, on the face of it, be good for climate change. After all, every tonne of carbon emitted by burning biofuels is just a tonne that was absorbed from the atmosphere by the feedstock crop, resulting in no net change. But it's not that simple. The energy used to create the biofuel also emits greenhouse gases.

If biofuels do provide more energy than the fossil fuels needed to produce them, it makes sense that there would be some reduction in greenhouse gas emissions. But the analysis has to take into account the kind of fuel used to produce the ethanol - ethanol made by using coal to provide heat for distillation, for instance, actually increases carbon emissions compared with gasoline - as well as the greenhouse gasses generated by other aspects of the process, such as increased fertilizer use.

In their Science analysis, Farrell and colleagues noted that there are still unanswered questions about how to calculate greenhouse gas emissions over the life cycle of biofuels ${ }^{6}$. They calculated that switching to ethanol produced from corn reduces emissions moderately, by about 13 percent, compared with using gasoline.

And a recent paper by P.J. Crutzen of the Max Planck Institute for Chemistry in Mainz, Germany, and colleagues concludes that previous studies underestimated the amount of the greenhouse gas nitrogen oxide produced by agricultural use of nitrogen fertilizer. If their new number is right, they say, ethanol made from corn could actually produce more greenhouse gases than the use of gasoline?

An even greater concern is that the increased demand for biofuels will cause farmers to cut down forests in order to plant more corn, sugar cane, oil palm trees or soybeans. According to an analysis by Renton Righelato of the World Land Trust in Suffolk and Dominick V. Spracklen of the University of Leeds, leaving the land forested would sequester two to nine times as much 


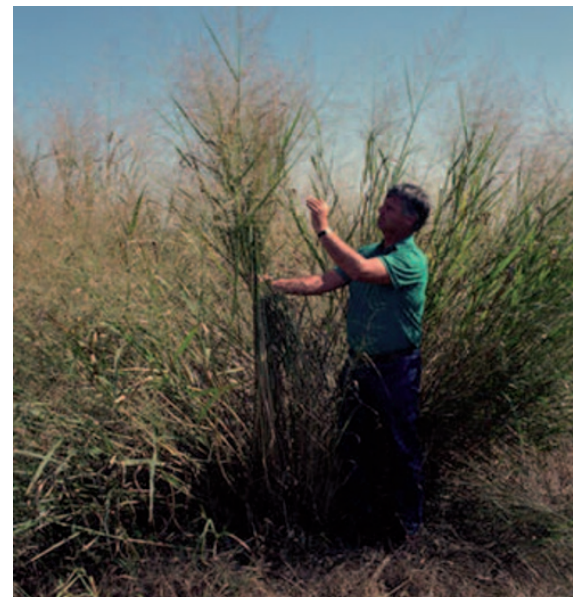

Switchgrass grown on marginal lands could yield cellulosic ethanol without affecting the food supply — but the grass can't yet be processed cheaply enough to put this biofuel on the market.

carbon over a 30 -year period as would be saved by using biofuels ${ }^{8}$.

In a study published in September, the World Wildlife Fund warned that biodiesel from palm oil will only have a positive environmental impact if the new plantations are planted on fallow land. If forests are cleared to create new plantations, the resulting biofuel will actually have a negative effect ${ }^{9}$.

\section{FOOD OR FUEL}

Another concern is that land that could have been used to grow food will be given over to growing crops for fuel.

"Rushing to turn food crops ... into fuel for cars, without first examining the impact on global hunger, is a recipe for disaster," the UN rapporteur on food said in his August report to the UN General Assembly. The report cited estimates that to fill one car tank with biofuel requires an amount of maize that would feed one person for one year.

The report noted that riots broke out in Mexico in February when the price of corn tortillas rose by over 400 percent, the result of an increase in the price of corn brought on in part by increased demand for corn ethanol.

"Agrofuel production is unacceptable if it brings greater hunger and water scarcity to the poor in developing countries," the report says. It concludes by calling for a five-year moratorium on biofuel production while new biofuel technology is under development.

\section{ANEW BREED OF BIOFUELS}

The technology many are counting on is called cellulosic ethanol. Unlike conventional bioethanol, which is based on sugars or starches extracted from the feedstock, cellulosic ethanol can be made from a plant structural material called lignocellulose, found in everything from corn husks to grasses.

Part of the promise of cellulosic technology is that for feedstock it could use plants like switchgrass, which can be grown on otherwise marginal lands, without irrigation or fertilizer, leaving prime farmlands for food. Agricultural waste such as corn stalks could also be used.

In 2005, the US Department of Agriculture and Department of Energy concluded that crop residues, forest byproducts and other underutilized resources could produce more than a billion tons a year of biomass for cellulosic conversion in the US alone, enough to replace 30 percent of US petroleum consumption by 2030 (ref. 10).

"As cellulosic takes hold, I believe we'll get much higher yields of grasses and so forth. We'll be making more efficient use of the land that we have," says Dale.

One of the many attractions of cellulosic ethanol is that producing it is potentially much more energy-efficient than using corn. Corn bioethanol requires an outside energy source to provide the heat needed for processing. But cellulosic processing separates the lignin from the cellulose and then burns the lignin to provide energy for distillation.

Fewer fossil fuels are used, which reduces carbon dioxide emissions. In addition, as long as the feedstock doesn't require nitrogen fertilizer, nitrous oxide emissions are cut. In a 2007 paper, Wang and colleagues concluded that use of cellulosic ethanol would reduce greenhouse gas emissions by 88 percent compared with gasoline ${ }^{11}$.

One problem: cellulosic ethanol isn't ready for market. There are a number of ways to break down cellulose into component sugars that can be fermented, including applying enzymes and chemicals. But the process is still too expensive to produce ethanol on a large scale at a competitive price.

On 6 November, the Range Fuels biorefinery broke ground in Soperton, Georgia, one of six cellulosic biorefinery demonstration projects being funded with US $\$ 385$ million from the US Department of Energy. The plan is for the biorefineries to produce 130 million gallons of cellulosic ethanol a year at a cost competitive with gasoline. Advocates say the technical advances in cellulosic ethanol will eventually achieve inexpensive, energy energy-efficient, non-polluting ethanol.

\section{ZERO-SUM GAME?}

But sceptics aren't so sure. "The fact is that with cellulosic ethanol, we don't have the technology yet. We need major breakthroughs in plant physiology. We might wait for cellulosic for a long time," Holt-Gimenez says.

Patzek and other sceptics worry that biofuels are a distraction from other steps that would make a real difference, including solar and wind power and conservation. They dismiss the biofuels boom as a result of government subsidies.

"This is a completely fictitious market. It's floated by the subsidies, tariffs and targets. If those weren't there, you wouldn't see this boom," Holt-Gimenez says.

He worries that biofuels will simply enrich agrobusinesses while at the same time driving countries in the south to switch cropland and forests over to fuel production.

The Worldwatch Institute also recognizes that danger. But in a 2006 report on biofuels, it concluded that if the biofuel industry is managed effectively, it could actually benefit the environment and third-world farmers, who could profit from growing the crops needed to produce the fuel ${ }^{12}$.

"I just don't see it as a zero sum game," says Raya Widenoja, a Worldwatch research associate who works on biofuels sustainability. "I believe there is enough land to produce food and also to produce some biofuels .... If it was done right, there's potential for farmers and developing countries to gain," she says.

\section{Kurt Kleiner is a freelance science writer.}

\section{Published online: 12 December 2007}

\section{doi:10.1038/climate.2007.71}

References

1. Ziegler, J. The Impact of Biofuels on the Right to Food. Report No. A/62/289 (United Nations General Assembly, New York, 2007); http://www.righttofood.org/A62289.pdf

2. Doornbosch, R. \& Steenblik, R. Round Table on Sustainable Development. Biofuels: Is the Cure Worse Than the Disease? Report No. SG/SD/RT(2007)3/REV1 (Organisation for Economic Co-operation and Development, Paris, 2007); http:// www.oecd.org/dataoecd/9/3/39411732.pdf

3. Renewable Fuels Association; http://www.ethanolrfa.org/ industry/statistics/\#E

4. Pimentel, D. \& Patzek, T.W. Nature Resour. Res. 14, 65-76 (2005).

5. Wang, M. in 15th International Symoposium on Alcohol Fuels (San Diego, 2005); http://www.transportation.anl.gov/pdfs/TA/354.pdf

6. Farrell, A.E. et al. Science 311, 506-508 (2006)

7. Crutzen, P.J. et al. Atmos. Chem. Phys. Discuss. 7, 11191-11205 (2007).

8. Righelato, R. \& Spracklen, D.V. Science 317, 902 (2007)

9. Reinhardt, G., Rettenmaier, N., Gärtner, S. \& Pastowski, A. Rainforest for Biodiesel? Ecological Effects of Using Palm Oil as a Source of Energy (World Wildlife Fund Germany, Frankfurt, 2007); http://www.wupperinst.org/uploads/tx_wibeitrag/wwf_ palmoil_study_en.pdf

10. Perlack, R.D. et al. Biomass as a Feedstock for a Bioenergy and Bioproducts Industry: the Technical Feasibility of a Billion-Ton Annual Supply (US Department of Energy and US Department of Agriculture, Washington, DC, 2005); http://wwwl.eere. energy.gov/biomass/pdfs/final_billionton_vision_report2.pdf

11. Wang, M. et al. Environ. Res. Lett. 2, 024001 (2007).

12. Biofuels for Transport: Global Potential and Implications for Sustainable Agriculture and Energy in the 21st Century (Worldwatch Institute, Washington, DC, 2006). 